\title{
Towards Streamlined Broadcasting: The Changing Music Cultures of 1990 Finnish Commercial Radio
}

\author{
Heikki Uimonen \\ heikki.uimonen@uta.fi \\ Dept. of Music Anthropology, University of Tampere
}

\begin{abstract}
The deregulation of broadcasting in 1985 Finland introduced competition between the European public service tradition and American commercial radio. Musically diverse and almost uncontrolled programme policies of the mid-1980s were replaced by the American-style format radio in the 1990s. The article focuses on how the process of music selection and radio music management changed. What were the economic, technological, organisational and cultural constraints that regulated the radio business and especially music? The question will be answered by empirical data consisting of interviews with the radio station personnel and music copyright reports supported by printed archive material.
\end{abstract}

Key words: radio music, deregulation, music programming, play lists, music selection.

\section{Introduction}

Yleisradio (The Finnish Broadcasting Company, YLE) was founded in 1926. Right from the beginning music had an important role accounting for nearly 70 percent of broadcast time. Soon the share was cut down but it still remained around 50 percent. Publicly funded radio broadcast live; recordings were used very seldom. It seems that the YLE had two main guidelines in their programme policy: firstly to provide serious and uplifting popular education and information to the public and secondly to meet the listeners' needs for entertainment. In practice this meant more highbrow than folksy style amusement (Kurkela, 2010, pp. 7273).

In the early 1960s the YLE policy was challenged when the pirate stations started to broadcast off the coast of Stockholm. This resulted in an increase of popular music in programmes in 1963. The second challenge to the YLE's reactive music policy was the active youth movement wanting to add more rock music to radio programmes in 1980. In fear of losing their young listeners YLE agreed to do so (Kemppainen, 2010, p. 26; Kurkela \& Uimonen, 2007, pp. 89). 
In 1985 the Ministry of Transport granted 22 experimental licences to Finnish local radio stations. Seven of them were connected to national or regional independent and political newspapers that considered the economic aspects to be one of the main reasons for starting the radio business. Idealism and somewhat subversive radio policies were connected to radios in major cities (Prt 1987, 5-9; Kurkela \& Uimonen, 2007).

The music contents were not brought into the discussion in the early days of commercial radio although it was self-evident that the new music dissemination medium was welcomed by the Finnish music industry. The music business was flourishing and new records were successfully released. For the first time Finnish rock sold best of the domestic music when compared to pop and iskelmä. In addition to that the record companies had found new audiences among young and adult rock listeners (Lassila, 1990, pp. 53-56). The listening culture had also been in change for some time. Since the 1960s people had listened to radio in the background while engaging in other activities at work and in leisure time instead of concentrating on listening (see for example Uimonen, 2009).

First the new radio hosts and deejays in special music programmes made broadcast music more diverse. The channels started to compete for who would be the first to broadcast the latest music releases. This was easy because, unlike the YLE, commercial stations were not tied to the time of the day or to the amount of broadcast music. In principle the stations could air as much music as they desired and thus challenge the YLE's rock programmes confined to a certain day and time of the week. Freedom of speech, musical diversity and the manysided policies were an integral part of broadcasting until the end of the 1980s.

The founding of the local stations was facilitated by the relatively cheap broadcasting equipment. However, media scholars Krister Malm and Roger Wallis (1992, p. 219) contend that politicians were fooled by those advocating the democratising effects of technology. This is hardly true for the first Finnish local radio enthusiasts and their idealism, who discussed extensively about democratic participation, new radio polices and local voices that would reach new audiences when the stations began broadcasting. However, Malm's and Wallis' rather pessimistic prediction was confirmed within the next ten years when subsequent chaining of the stations, music formatting and streamlining were introduced.

In the early 1990s more licences were granted, which increased the competition. The streamlined channels reduced the diversity of music genres. Until then music and individual songs had been fairly independent elements in broadcasting, but now they were integrated more closely into the business strategy of the station. The arguments invoking freedom of speech and diversity were replaced by a channel sound and topics suitable for format radio targeted at a particular audience segment. The new foundations for radio were laid on listener groups, centralised music selection and music research.

The public discussion on the matter is relatively often connected to the aforementioned issues. It seems that only somewhat fragmentary arguments are 
presented. On the one hand there is the idealism and musical diversity of the mid-1980s radio, on the other there is international ownership, chaining of stations, limited playlists and the fading hopes for media democracy. No matter how true or false these arguments may be, they are seldom backed up by facts relating to changes in the history of Finnish commercial radio.

Historically, the transformation of the business culture came about gradually and for different reasons. This article searches for an explanation for the changes in production culture and the music programming tied to it. The text emphasizes the early 1990s because at that time American-style format radio was not yet fully established but seeking its way in Finland. Production cultures have changed since then because of digital innovations, for example, but basically similar music auditorium research and music selection practices are currently in use. They therefore deserve to be documented.

The theoretical frame of the article draws on Malm \& Wallis (1992, 25-29). In the research Media Policy and Music Activity they theorize that the music industry operates on three levels: local, national and international. On these levels, various kinds of interaction occur between different participant groups or actors. This interaction is affected by five factors: economy, technology, legislation, organisation and culture. This interaction is clearly discernible in the change of Finnish commercial radio.

The article sheds light on the factors affecting the music policies of commercial radio stations manifest sonically in the broadcast music of local and semi-national radios. The empirical data consists of interviews with radio station personnel, music copyright reports and written archive material. Radio Sata, founded in the southwestern Finnish city of Turku, will be examined in more detail. The station was active and innovative in constructing its music content and form in accordance with American-style format radio.

Furthermore, Radio Sata created local and semi-national music policies in consulting various radios, which clearly transformed the radio policies towards more formatted radio not just in south-western Finland but in other parts of the country as well. Radio 957, formerly owned by the Student Union of University of Tampere, was one of those consulted and is therefore also presented here in more detail. Both stations ended up in the possession of the multi-national Scandinavian Broadcasting Systems (SBS) with identical playlists and thus exemplify the transformation of the Finnish radioscape in general level. ${ }^{1}$

\section{Business culture, music management and technology}

At the turn of the 1990s the Finnish commercial radio was economically flourishing. The turnover of the entire business rose from FIM 10 million to FIM 235 million (1.6/39 million euros) from 1985 to 1990. The competition situation had changed as well as the number of radios had increased from 18 to 66 (Joukkoviestimet 1998, pp. 157-158). 
The increased competition altered the contents broadcast by the stations, especially in towns with two commercial radios. The number of artists and genres broadcast had decreased and the predictability and uniformity of the station had become a virtue. This was affected by listeners' preferences and the programme policies of competing stations: music was now targeted at a certain group so as to attract a sufficient number of radio advertisers. The prime time music especially, from approximately 6.00 to 18.00 , had to appeal to the largest possible listener group (Tuominen, 1992). A format radio station is bound to streamline its content so as to meet the target groups expectations. This cannot be done without replacing diversity with uniformity (Lowe, 1992, p. 200).

Radio Sata was founded in 1989 in Turku to challenge another local commercial channel, Auran Aallot. The new station was targeted at young adults and middle-aged listeners from 25 to 50 years of age. The rapid change towards American style, streamlined commercial radio was intentional and well thought out. (Heikkilä, 1991; Purssila, 2008). A radio station was little by little transformed into a product that needed to be controlled as much as possible, including music management.

The format ideology of Radio Sata was founded on the experience of the domestic and international music and radio business. In the 1980s the interior design in Finnish restaurants was enhanced by background music targeted at the clientele. According to the music director of Radio Sata this can be attributed to an early form of formatting in Finland: music from 1960 to 1980 including contemporary hit songs was selected and targeted at a certain group (Sjöman, 2008).

The music director's comment sets target group thinking and music selection in a broader context, namely the change in music consumption and listening culture starting from the late 1920s in Finland. Portable gramophones liberated music listening from a certain place and time. Transistors and car radios and the cassette culture of the 1970s enhanced the phenomenon. Music became the listener's constant companion; it was no longer connected only to festivities, dances or concerts. (See Kurkela, 2005; Uimonen, 2009.)

Radio Sata was active in searching for up-to-date information on the innovations and the latest trends in the radio business. The radio stations in the USA and the international media events such as NAB Shows (National Association of Broadcasters) were visited regularly. The participation was quite objective-oriented: the lectures, memos, literature and the taped radio programmes were analysed and then combined in the materials distributed in training sessions of the station (Purssila, 1993a; 1993b; 2008).

The teaching material of Radio Sata consisted of photocopies of Finnish and English scientific articles, newspaper articles and studies on commercial radio. Concrete methods of broadcast editing were also included. An article dealing with the new form of public broadcasting of the Canadian Broadcasting Corporation was heavily underlined. It stated that single programmes were not relevant to audiences; the prime time was daytime, not evenings; radio was a 
local medium, and hosts should be personalities who attract and hold audiences. (Purssila, 1993a; 1993b). These were the major changes that also took place in Finnish commercial radios.

Radio Sata was aware that adults listened to the radio for longer periods than the young: music "did not play a fundamental role in their lives". Because of this the music selection was guided by nostalgia. 25-year-old listeners would like to listen to the music that they listened to when they were 13 to 15 years of age. The playlist was compiled of that era's music. The selection process was quite challenging considering that 50-year-old listeners had experienced their memorable musical moments twenty-five years earlier. The possibly irritating genres were abandoned and in order to attract female listeners the station abandoned sports programmes (Purssila, 2008; Sjöman, 2008).

Radio Sata received the broadcast music from the record companies or purchased it from the local record shops. Hit music was not of paramount importance because the station was not targeted at young listeners. Actually it was more suitable for the station's policy if the competing channel or television made the hit instead of them. Radio Sata did play new songs but their "test slots" were precisely defined in the streamlined programme flow. The feedback was received immediately from active listeners (Sjöman, 2008).

In the early days of commercial radio the channels gained a competitive advantage by broadcasting the recent releases before their competitors. In the 1990s the radio music culture was changed by target group thinking: in a certain format the competitor's hit making was considered not just worthy of support but also economically lucrative. It became a risk for a channel playing nostalgic music to broadcast an unknown song because it might drive a listener away to another frequency.

Radio Sata's corporate culture differed from those of competitors in this respect. Centrifugal elements in broadcasting were considered more important than the centripetal ones. This obviously catered for background listening: entertaining, non-disruptive and nostalgic music is appropriate to accompany daytime activities.

Not only the music but also the studio equipment was updated. Radio Sata and Data City Communications had designed, planned and constructed a device called the CD Music Editor, which could control eight Sony CDK-006 CD players, each of them holding 60 CDs (see Figure 1; Ahto, 2008). With the new music scheduler the nature of music selection was profoundly changed because handling it became intangible. In addition, the CD Music Editor enabled the unoccupied use of the studio and made evening and night broadcasting more cost-effective. (See Figure 2.) 


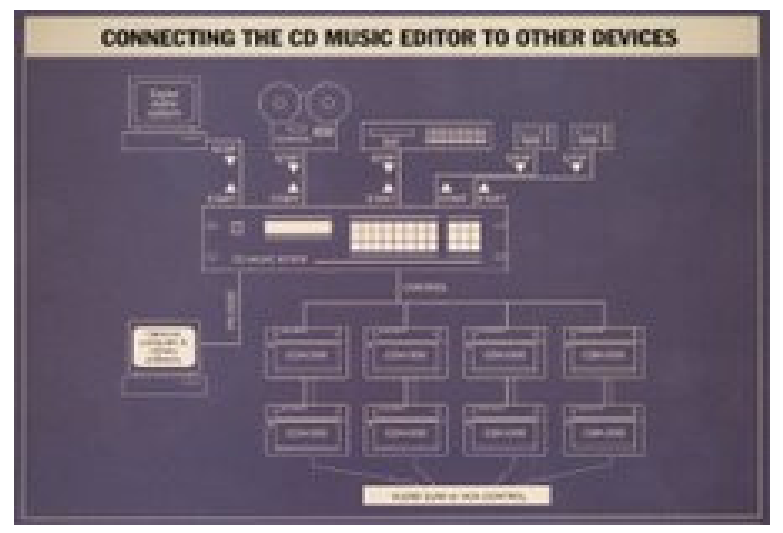

Figure 1: CD Music Editor and the radio station equipment (brochure).

By launching the CD Music Editor the radio programming needed a transition to format thinking because night-time broadcasting necessitated the categorization of music. The device was controlled by the 30-key keyboard unit, which was later converted into computer controlled music management software and incorporated into Radioman music management products (Ahto, 2008).

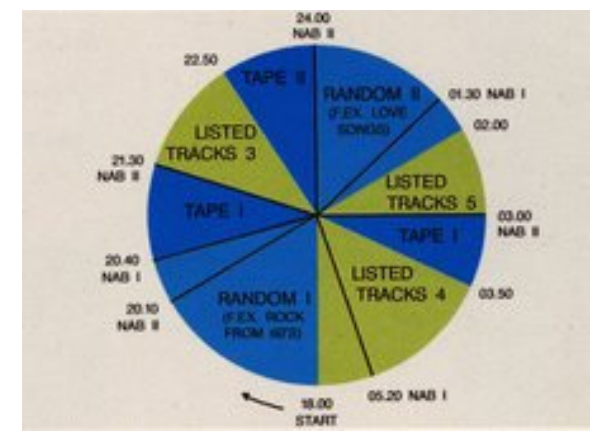

Figure 2. Night-time programming with the CD Music Editor (brochure).

The early format radio music selection was not completely automated. Radioman offered choices from the music bank with rated songs (such as domestic new release/foreign classic), which were then selected by the show host. For instance, a song with a rating from 8 to 9 was broadcast relatively often, whereas a song with a rating of 5 was heard hardly once a month. The playlist was composed hand in hand with the rotation clock that geared to the daily rhythm of the listeners and their possible feeling of afternoon drowsiness (Purssila, 2008; Sjöman, 2008).

The principle closely resembles that of the well-known background music enterprise Muzak Corporation. The Stimulus Progression method from the 1940s aimed to relieve the drowsiness of workers by the music selection. (Lanza, 1995, pp. 48-49). Similar to the current radio formatting the songs were labelled according their suitability, for example "Gloomy - minus three/Ecstatic - plus eight". 
Public discussion about the music content in radio generally revolves around the individual songs or their repetitive broadcasting. The radio business culture of the early 1990s changed the focus to a more holistic view. Instead of individual songs it was considered more important to concentrate on the station's channel sound. It consisted of the compatibility of jingles, music and openers, which are the high-rated songs broadcast immediately after the advertisements (Purssila, 2008).

\section{Music research as an integrated part of production culture}

In the 1990s music testing was established as an essential part of the radio channels' production culture, music scheduling and advertising. The station brochures presented the professional radio stations as founding their business on research-based knowledge about the listeners who could thus become a potential segment for potential advertisers (Tutkittu radio, 1993).

The launching of music testing was connected to the tougher competition of the commercial sector in the radio business. In Finland the tradition was virtually non-existent, although some special studies were carried out soon after the YLE started broadcasting in 1926. Listeners' opinions on the classical music, folk and popular music were registered. There was no need for research due to the monopoly position of the public service channel. However, some of them were accomplished in 1977, when the music content was evaluated statistically and the opinions of the listeners concerning the "light music" were surveyed (Kurkela, 2005, pp. 109-112; Kurkela \& Uimonen, 2007; Kemppainen, 2008).

Furthermore, the modes and places of listening were now different. In the commercial radio of the 1990s scheduling of music, news and weather forecasts was based on the idea of fragmented listening. The policy was to create optimal content for the fifteen-minute or half-hour period of time when the radio was listened to while commuting. The idea was based on KRT (National Radio Research), which was a collaborative study carried out by the YLE and commercial radios. Informants estimated their radio listening in fifteen-minute periods by filling in so-called radio diaries (Ahto, 2008; KRT, 2009). Interestingly, the aforementioned Muzak's Stimulus Progression method was also based on fifteen-minute sequences (Lanza, 1995, p. 49).

According to Radio Sata personnel, the importance of KRT lay in the public availability of information concerning the radio markets and that this information was taken into consideration in the decision-making of the media companies and advertisers. However, it was insufficient for the radio station's strategic planning, which required more profound information on radio listening. In addition, Radio Sata analysed their competitor's broadcasting. The places of advertisements, broadcast music, rotation of the songs and jingles were monitored and notated with the aim of gathering the empirical evidence on the competitor's activities. This was aptly described in an urban legend of the 1990s in Turku: if Radio Sata painted its walls blue on Monday, the walls in the competing station were also blue by Friday (Ahto, 2008; Purssila, 2008). 
Furthermore, qualitative research methods were utilised in marketing. Radio Sata invited approximately one hundred listeners to a lunch, during which opinions on the station were elicited by interview research. Music preferences were considered essential, because if there was any loss of listeners, the blame would first be put on music (Sjöman, 2008).

\section{Radio Sata: A mission in the Finnish City of Tampere}

Radio 957 started to broadcast on 15 August 1985. The licence was granted to the Student Union of the University of Tampere. Contrary to the common trend, the application specified the alternative communication policies which would "emphasize the new cultural trends quickly absorbed by students". Furthermore, the active role of the Student Union on the local music scene was noted (Tamy, 1984; Kurkela \& Uimonen, 2007). The channel was targeted at all Tampere region residents, not just students or music lovers. However, diverse music genres and artists were broadcast not only in special programmes but also during the prime time.

Radio 957 faced serious financial problems at the turn of the decade, when two more licences were granted in Tampere. The biggest single change in production culture took place in 1992, when Radio Sata acquired 75 percent of the Radio 957 shares. The new music content was planned in accordance with music research aiming to find the assorted and exclusive artists and songs that would suit the vast majority of local music listeners, no longer specific music audiences.

The new Radio 957 was targeted at young adults according to so-called artist research. Five hundred interviews were used to ascertain local music preferences, which led to the conclusion that Tampere was more "rock-oriented" than to other towns and that the townspeople's "rock age" lasted longer. The company that carried out the work claimed that after the research Radio 957 listeners increased by thirty percent and thus the station became the most listened to channel in the area (Tampereen Markkinatieto, 1995).

Another study carried out by Radio Sata and Radio 957 showed that rock and iskelmä (Finnish schlager) were listeners' two main favourite genres. It turned out that iskelmä fans were more tolerant of rock than vice versa so it was safe to increase the amount of rock music in the content targeted to them. (Ahto, 2008; Purssila, 2008). Without doubt this change of attitude was caused by the ubiquitous presence of rock music in the media. Music formerly connected with young and marginal groups was now heard on television series, sports programmes and grocery shops. This had softened the attitudes of the wider audience towards formerly revolutionary music. (See Kurkela \& Uimonen, 2007).

Two years after the renewal in September 1994, Radio 957 broadcast 143 tunes in prime time. The music aired was fairly evenly divided between songs released in the 1960s, 1970s and 1980s (twenty/twenty-two/twenty-four percent respectively). The music released in the 1990s dominated with one third of music 
broadcast. The releases of 1994 accounted for fifteen percent of the total amount of music broadcast (twenty-two airings). The share of domestic and AngloAmerican music was respectively forty-eight and fifty-two percent during prime time. When music broadcast outside prime time is included, the percentage of Finnish music decreases to thirty percent (Gramex, 1994). All in all the music content was composed of familiar and nostalgic tunes.

The individual songs were broadcast twice, but they were performed by different artists. California Dreamin' by Mamas and Papas and the Beach Boys and Venus by Shocking Blue and Bananarama were heard in one day. Old and new Finnish schlagers and Anglo-American all-time rock favourites such as the Beatles and Elvis were broadcast. Easy listening rock was accompanied by Finnish iskelmä favourites.

Radio Sata's music profile was likewise thoroughly made over. Heavy rock, rap, old Finnish schlagers, disco, classical music, folk music, jazz and religious music were banned (Tuominen, 1991). In September 1994 Radio Sata broadcast 118 performances in prime time, half of them domestic (52 percent). Domestic neo-schlager singers were aired more than on Radio 957. The Beatles and Elvis were accompanied by such artists as Don Henley, Tina Turner and the Sailor (Gramex, 1994).

Because the availability of CDs was relatively poor in the early days of Radio Sata, they decided to purchase a collection of one hundred CDs from the USA meant for radio use. It included the essential performances of various artists. These compilations determined the style of American music broadcast by the station for some time. Finnish CD compilations were also utilised (Ahto, 2008).

The costs of the evening programmes were reduced by broadcasting nonrevenued material such as classical music and nature sounds such as sounds of the sea and seagulls. These were replaced by an innovation called Radiojukebox. The aforementioned CD Music Editor was connected to a device called CDME Telephone Interface. By using the tone-dialling phone and dialling a code one could select a song which would be then be played by the automated system at a cost of FIM 5 (80 cents) per request (Ahto 2008; Purssila, 2008).

Jukebox was considered an important innovation in relation to profiling the station because right from the beginning Radio Sata was able to distinguish itself from its competitors. The song lists were published in a magazine/leaflet called Radiojukeboksi with a listing effective for six months. The paper was distributed in the premises of the companies that advertised in the paper and in local post offices. For the station the new device was a very convenient way to collect feedback on the music because every broadcast song was logged to the file and then utilised in compiling the playlist (Ahto, 2008; Purssila, 2008).

Jukeboksi 1/1994 listed approximately 2200 songs mainly by Finnish and Anglo-American artists for the radio listeners to select their favourites. The top ten songs included Finnish schagers spiced up by Whitney Houston: I will always love you, Bryan Adams: Everything I do I do it for you, a French kid Jordy: Dur 
dur d'etre bebe, and UB 40: I can't help falling in love with you (Jukeboksi, 1/1994).

The paper concluded that top ten listing indicated the emergence of neoschlager in Finland, which is quite correct if estimated by the artists and publishing year. The songs consist mainly of schlagers and adult-oriented rock with nine out of ten released in the 1990s. The schlager enthusiasm of the listeners foreshadowed the success of the genre, which later resulted in a seminational radio chain named Iskelmä formatted to play neo-schlagers and assorted songs from other genres. In Tampere Jukeboksi was played with more limited songs excluding the neo-schlager artists, which leads to the conclusion that local music tastes were considered part of formatting in the early 1990s.

Not only formatting but also technological innovations were introduced in order enhance the channel sound and the competitiveness of the station. The balance between speaks and music was improved by headphones-microphone headsets worn by the show host and the guests. The distance between the speaker and the microphone and thus the volume remained constants during the show. The headsets were acquired in order to compete with the YLE on sound quality. In the YLE studio sound engineers monitored the broadcasting, whereas the commercial stations had to rely on studio hosts. The sound compression narrowed the gap between speech and music and improved fringe area reception (Ahto, 2008).

Compression had no effect on the music selection process concerning rock, pop or schlager genres. With classical music it was all different. Radio Sata founded Classic Radio in Helsinki in 1992 and realised that the 1990s sound technology was insufficient for classical music. The problem was solved by selecting chamber music or solo works in prime time with less dynamics than in orchestral works. Compression would not be noticed to when music was listened from low-fi car stereos and radio receivers. Classic Radio also took advantage of CD Music Editor and writable CDs in music selection and announcements. The costs were reduced by recording speaks on CDs, loading them onto a programmable $C D$ player and broadcasting them immediately after the music (Ahto, 2008).

\section{Redefining target group thinking}

The brand marketing of the mid-1990s guided format thinking towards more strictly defined listener segmentation. Different lifestyles were combined with music styles and speech content was steered towards the phenomena considered important to listeners (Ahto, 2008).

By 1994 the multinational Scandinavian Broadcasting Systems (SBS) had acquired 75 percent of Radio Sata's and 100 percent of Radio 957's shares. With the new business culture targeting was further narrowed by collecting facts about listeners. Occupation, hobbies, consumer and reading habits and television watching were ascertained. A potential radio listener was even given a name: in 
2006 Radio 957 targeted its programmes at a virtual person called "Masa, aged 36" (Raeste, 1994; Siljamäki, 2006; Sjöman, 2008). BBC was using a virtual couple "Dave and Sue" for the same purpose (Kelner, 2008).

SBS left the domestic music selection process untouched. However, the multinational company was able to provide research findings on the company's radios and how they could be applied to Finland. Previously problematic high costs of music auditorium testing were no longer considered an issue, although it must be noted that Radio Sata and Radio 957 co-operated in order to reduce the costs (Sjöman, 2008).

In auditorium music testing the samples of songs are played to the group of people evaluating them with the help of a certain selecting device (see Uimonen, 2009). The songs were tested in collaboration with a company specialized in music testing. The music director's job was to pick the song from the music-scheduling programme. The music directors of the corporation also discussed the suitability for songs to different stations of the SBS. Gradually the music content was unified in SBS stations belonging to the same radio chain. The announcements were centralized to a single station in Tampere. It was more cost efficient to use one music director and one host instead of four (Ahto, 2008; Purssila, 2008; Sjöman, 2008).

When more radio licences were granted, Radio Sata's personnel began to offer their tested and accomplished business solutions to other commercial stations. A limited company called Communication Design was founded to offer new radio entrepreneurs a total "package" consisting of planning the business, constructing the studio and station's premises, planning the programme profile, sales and image marketing and training personnel. Previous experiences were utilised and tailored to meet the requirements of the new radio according to prevailing competitive situation. Communication Design had some twenty business partners all over Finland (Ahto, 2008; Sjöman, 2008).

In 1996 Data City Communications carried out research aiming to combine music tastes charting with the images pertaining the commercial stations. First auditorium music testing was used to ascertain the music and artistic preferences of the listeners. The results were then placed on a map, which showed that if a listener was fond of a certain artist he or she would probably prefer similar songs or singers (Ahto, 2008; Hollmén, 2008).

The research was combined with telephone interviews. Informants were asked to evaluate the suitability of certain pop and rock groups as content for a radio channel on a scale from one to seven. Alternatively the informants were played few-second hooks (i.e. refrains or catchy melodies) and asked, if they would listen to a channel playing that kind of music. They were also asked if the samples matched the contents of current radio stations. The testing was not meant to evaluate the actual music content but the image of the stations (Ahto, 2008).

By combining the map and telephone interview results the researchers aimed to identify the matching artists and songs, music tastes of different age 
groups and especially the images associated with the stations. Similarly, the potential listeners without any radio station were scrutinized. This was justified by the fact that the conceptions concerning the channel and the channel sound of the station were very often different among the radio personnel and the listeners. When a new station went on the air, it clearly also changed the image of the old station. This usually resulted in the re-profiling of the old radio with the appropriate research (Ahto, 2008).

In the late 1990s image marketing it was essential to conquer a given "space" before the competitor. This position could be achieved for example with a slogan connected to music and to the radio station. More important to the actual broadcast content was the notion of what the station presumably broadcast. The assumption and the actual music content were not necessarily identical (Ahto, 2008). In relation to radio music research this actually challenges the role of the music, artist or an individual song when listeners evaluate the suitability of the station for themselves.

\section{Conclusion}

The formatting of Finnish commercial station is part of a more extensive transformation of music and listening cultures. The rotation clocks continued the policies initiated by the background music companies that matched the music content to daily routines of the listeners and the social uses of music. Before the local radios started broadcasting music was one segment of radio content, not yet the essential part it became in the 1990s.

Musically diverse and unconventional programmes were gradually converted to streamlined broadcasting. American-style format radios were introduced with automated music control, playlists and audience music testing. The changes were fostered by the increased competition caused by the change in the broadcasting regulations, the unexpected economic recession and technical innovations such as music jukeboxes. These business policies form the foundation on which current commercial radio still rests.

Streamlining and the multinational ownership did not simply replace the experimental music content and broadmindedness of the early days. The changes in production cultures took place gradually and in synergy with other factors. The granting of broadcast licences at the turn of the 1990s created competition which led to a situation in which genres and other content believed to be irritating were removed from prime time.

Radio 957 and Radio Sata composed their playlists strategically in accordance with local music tastes, although the artists and songs are very similar. The continuous broadcasting of an individual song was not characteristic of either station because the music was targeted at middle-aged listeners and the intense hit rotation was more typical of channels targeted at a younger audience. 
Drawing on Malm \& Wallis, the actors in the music business are affected by economy, technology, legislation, organisation and culture. The Finnish radio business professionalized in relation to consumer segments and music selection: centralized music selection made it easier to target certain music at specific listener groups. Economic considerations limited the music selection because the copyright revenues differed depending on the music. Domestic releases and music from the countries of the Rome convention were more expensive than for example music from the United States. On the other hand, the issue has been subject to different interpretations and estimations. The price of domestic music has been considered cheap or expensive depending on the position of the commentators, who are usually representatives of copyright organizations, commercial radios or the musicians' union.

The introduction of format radio was accompanied by technological innovations. At the same time they steered the radio production cultures in new directions: automated night-time broadcasting was more cost effective that running an occupied studio. Following the latest innovations in broadcasting and studio technology and keeping up with changing radio production cultures and consumer research became an essential part of the radio business. The image marketing was strengthened as well, although it was nothing new in Finnish commercial radio. Right from the start Radio City operating in the Helsinki area for example, positioned itself as a more rock oriented channel for young listeners and thus differentiated itself form competitors targeting their programmes at somewhat more middle-aged listeners.

So far there has been no detailed research on the changes in broadcast music caused by the chaining of individual stations and so-called special radios (such as Kiss FM, founded 1995). The changes were again influenced by digitalization, which enabled centralized broadcasting control: the music content of a whole chain of radios could be managed by a single computerized system, with a limited number of employees and from one place.

However, it was clearly visible that the new radioscape challenged the channels to adapt new American style broadcasting. Tight playlists made it even more difficult for the new music-makers to have their songs aired when compared to established artists suitable for the channel sound of the radio. Music was soon selected only in terms of business, which evidently impaired the diversity of broadcast music - especially when evaluated on the basis of different genres or individual artists aired.

\section{Notes}

1. The text is based on article Lännen malliin - Radio Sata ja 1990-luvun musiikkiradiouudistus published in Kulttuurintutkimus 26 (2009):1, pp. 25-38. 


\section{References}

Ahto, Markku. 2008. Radio entrepreneur Markku Ahto, Radio Sata, interviews in 13 \& 18 November, 4 December 2008, Heikki Uimonen, in the author's possession.

CD Music Editor. 1990. Brochures from early 1990s, Markku Ahto's archive.

Gramex. 1994. The broadcast music of Radio 957, Copyright Society's music reports, 7 September.

Heikkilä, Markku.1991. Manager Markku Heikkilä, Radio Sata, interview 5 July 1991, Harri Tuominen.

Hollmén, Jaakko. 2008. Jaakko Hollmén, interview 10 December 2008, Heikki Uimonen, in the author's possession.

Joukkoviestimet. 1998. Joukkoviestimet, Tilastokeskus, Helsinki.

Jukeboksi. 1994. Jukeboksi 1 /1994. Brochure. Markku Ahto's archive.

Kelner, Martin. 2008. "Heard the same song three times today? Blame the craze for 'testing' tunes'”, Guardian, 19 May.

<http://www.guardian.co.uk/media/2008/may/19/radio.bbc1> [Accessed 7 Mai 2010].

Kemppainen, Pentti. 2008. Researcher \& programme manager Pentti Kemppainen, Interview December 2008, Heikki Uimonen, in the author's possession.

Kemppainen, Pentti. 2010. "Pirates and the new public service radio paradigm" in V. Kurkela, M. Mantere \& H. Uimonen eds. Music Breaks In. Essays on Music Radio and Radio Music in Finland, Department of Music Anthropology, University of Tampere, Tampere, pp. 15-30.

KRT. 2009. Kansallinen radiotutkimus, 29 April. <http://www.finnpanel.fi/radio.php> [Accessed 7 Mai 2010].

Kurkela, Vesa. 2005. "Kirkuvat sopraanot ja ihana Markus-setä. Varhaisten radioäänten kulttuuriset ristiriidat" in O. Ampuja \& K. Kilpiö eds. Kuultava menneisyys. Suomalaista äänimaiseman historiaa, Turun historiallinen yhdistys, Turku, pp. 98-121.

Kurkela, Vesa \& Uimonen, Heikki. 2007. "Usko, toivo ja petollinen rakkaus. Rockkulttuuri ja suomalaisen radiopolitiikan muutos" in M. Mantere \& H. Uimonen eds. Heikki Etnomusikologian vuosikirja 19 (2007), Suomen Etnomusikologinen Seura, Helsinki, pp. 9-28.

Kurkela, Vesa. 2010. "Screaming Sopranos in Radio. Irritating and Pleasant Voices in Early Radio Broadcasting in Finland" in V. Kurkela, M. Mantere \& H. Uimonen eds. Music Breaks In. Essays on Music Radio and Radio Music in Finland, Department of Music Anthropology, University of Tampere, Tampere,pp. 71-83.

Lanza, Joseph. 1995. Elevator Music. A Surreal History of Muzak, Easy-Listening and other Moodsong, Quartet Books, London. 
Lassila, Juha. 1990. Mitä Suomi soittaa? Hittilistat 1954-1987. Jyväskylän yliopisto, Jyväskylä.

Lowe, Ferrel G. 1992. "Virtaviivaistetun formatoinnin työkalupakki" in A. Alm \& K. Salminen eds. Toosa soi. Musiikki radion kilpailuvälineenä, Yleisradio, Helsinki, pp. 200207.

Malm, Krister \& Wallis, Roger. 1992. Media Policy and Music Activity, Routledge, London.

Prt. 1987. Paikallisradiotutkimus. Paikallisradiokokeilun seurantatutkimus. Valtion painatuskeskus, Helsinki.

Purssila, Kari. 1993a. Radiojuontajan pieni kehitys- ja rytmitysopas. Kimmo Sahramäki's archive.

Purssila, Kari. 1993b. Radiotoiminnan perusteet. Kimmo Sahramäki's archive.

Purssila, Kari. 2008. Journalist Kari Purssila Radio Sata, interview 15 November 2008, Heikki Uimonen, in the author's possession.

Raeste, Jukka-Pekka. 1994. Radio Sata, Radio 957 ja Radio City saivat amerikkalaisen omistajan. Ulkomainen SBS tunkeutui suurkaupunkien radioihin in Helsingin Sanomat, 18 December.

Siljamäki, Anna-Maria. 2006. Tiivistetty paikallisuus : Radio 957:n paikallisuuden tarkastelua uutisten avulla, MA theses, University of Tampere.

Sjöman, Gösta. 2008. Music director Gösta Sjöman, Radio Sata, interview 12 November 2008, Heikki Uimonen, in the author's possession.

Tampereen markkinatieto. 1995. Brochure. Jari Niemelä's archive.

Tamy. 1984. Tampereen yliopiston ylioppilaskunnan paikallisradiotoiminnan periaate. Attachment to the radio licence application of Student Union of University of Tampere. Jari Niemelä's archive.

Tuominen, Harri. 1992. "Korvaluomia ei ole! Katsaus paikallisradioiden musiikkipolitiikkaan" in A. Alm \& K. Salminen eds. Toosa soi. Musiikki radion kilpailuvälineenä. Yleisradio, Helsinki, pp. 108-121.

Tutkittu radio. 1993. Brochure of Radio 957. Jari Niemelä's archive.

Uimonen, Heikki. 2009. "Haitaribussi. Kaupallisten radioiden musiikkivalinnat kaupunkitilan muokkaajina" in S. Ridell \& al. eds. Julkisen tilan poetiikkaa ja politiikkaa, Tampere University Press, Tampere, pp. 60-90. 